\title{
In vitro corrosion of metallic orthodontic brackets: Influence of artificial saliva with and without fluorides
}

\author{
Mônica Pereira Saporeti', Enio Tonani Mazzieiro², Wisley Falcco Sales ${ }^{3}$
}

\begin{abstract}
Objective: This in vitro study verified the resistance to corrosion of metallic brackets, evaluating the superficial aspects in scanning electron microscopy (SEM) and the residual components. Methods: The sample consisted of 17 sets of brackets of four different metallic alloys: Titanium, Cobalt-Chromium, Stainless steel with low nickel concentration and with titanium nitride coating (NiTi). Twelve sets were submitted to corrosion by immersion in $50 \mathrm{ml}$ of artificial saliva (pH 6.5) and four in saliva (pH 6.5) containing fluoride ( $2 \mathrm{~g} / \mathrm{l}$ ), all at a temperature of $37^{\circ} \mathrm{C}$ and analyzed after 7,9 and 11 weeks. One was kept as control set. The analysis consisted in qualitative evaluation of the corrosion by the images obtained on the SEM, in semiquantitative evaluation of chemical composition of the surface residue by SEM-EDS and the amount of ions released in saliva on evaluation of atomic absorption spectrophotometry. Results: The results showed that the pure titanium brackets and the ones with low nickel concentration were superior regarding resistance to corrosion. The cobalt-chromium alloy showed the greatest corrosion. In the presence of fluoride, it was observed greater variation in all alloys, especially in the ones of NiTi coated steel and the ones of cobalt-chromium. Conclusion: Although observed corrosion on the SEM, the spectrophotometry showed low ions release in the artificial saliva, however, the presence of fluoride negatively affected the corrosion resistance.
\end{abstract}

Keywords: Corrosion. Fluoride. Orthodontic brackets. Stainless steel. Titanium. Chromium alloys.

Objetivo: este estudo in vitro verificou a resistência à corrosão de braquetes metálicos, avaliando-se os aspectos superficiais em microscopia eletrônica de varredura (MEV) e os componentes residuais formados. Métodos: a amostra consistiu de 17 conjuntos de braquetes de quatro diferentes ligas metálicas: titânio, cobalto-cromo, aço inoxidável com baixa concentração de níquel e com cobertura de nitreto de titânio (TiN). Doze conjuntos foram submetidos à corrosão por imersão em $50 \mathrm{ml}$ de saliva artificial $(\mathrm{pH}$ 6,5) e 4 em saliva $(\mathrm{pH}$ 6,5) contendo flúor $(2 \mathrm{~g} / \mathrm{l})$, todos sob temperatura de $37^{\circ} \mathrm{C}$, e analisados após 7,9 e 11 semanas. Uma montagem foi mantida como controle. As análises consistiram na avaliação qualitativa da corrosão por meio das imagens obtidas no MEV, na avaliação semiquantitativa da composição química dos resíduos superficiais por meio de MEV-EDS e da quantidade de íons liberados nas salivas na avaliação da espectrofotometria de absorção atômica. Resultados: os resultados demonstraram que os braquetes com liga de titânio puro e os de aço com baixa concentração de níquel foram superiores em relação à resistência à corrosão. A liga de cobalto-cromo foi a que apresentou maior corrosão. Na presença do flúor, observaram-se maiores alterações em todas as ligas, com destaque para as de aço cobertos com TiN e as de cobalto-cromo. Conclusão: apesar de se observar a corrosão no MEV, a espectrofotometria mostrou baixo desprendimento de íons nas salivas artificiais, porém a presença do flúor interferiu negativamente na resistência à corrosão.

Palavras-chave: Corrosão. Flúor. Braquetes ortodônticos. Aço inoxidável. Titânio. Ligas de cromo.

${ }^{1}$ MSc in Orthodontics, PUC-MG

${ }^{2} \mathrm{MSc}$ and $\mathrm{PhD}$ in Orthodontics, USP, Bauru.

${ }^{3} \mathrm{MSc}$ and $\mathrm{PhD}$ in Mechanical Engineering, UFU.

Contact address: Enio Tonani Mazzieiro

Av. Contorno 8000 sala 1004, Santo Agostinho, Belo Horizonte, MG - Brazil

CEP 30110-932 - Brazil

E-mail: mazzieiroetm@gmail.com

\footnotetext{
How to cite this article: Saporeti MP, Mazzieiro ET, Sales WF. In vitro corrosion of metallic orthodontic brackets: Influence of artificial saliva with and without fluorides. Dental Press J Orthod. 2012 Nov-Dec;17(6):24.el-7.

Submitted: October 31, 2008 - Revised and accepted: August 16, 2012

» The author reports no commercial, proprietary or financial interest in the products or companies described in this article.

» Patients displayed in this article previously approved the use of their facial and intraoral photographs.
} 


\section{INTRODUCTION}

The release of metallic ions and the associated biological effects of the nickel alloys have received attention in literature of biomedical materials. Some researches ${ }^{6,17,25}$ have focused the in vitro phenomenon that occurs with it, including toxicity and allergenicity. The biocompatibility of the use of nickel alloys in the oral cavity for long periods of time has promoted the study of alternative materials for orthodontic patients. The oral environment is particularly ideal for biodegradation of metals, ${ }^{1}$ facilitating the corrosion process on orthodontic appliances. For this reason, nickel-free alloys or alloys of stainless steel with reduced amount of nickel have been tested. ${ }^{17}$ Studies $^{1,4,8,11,12,18,27}$ confirmed the possibility of in vivo and in vitro corrosion of steel brackets and associated a lower or greater potential of corrosion not only to the metal used, but to the manufacturing process and to the final structure of these appliances. The pure titanium was recently introduced as alternative material for metallic brackets for its low allergenicity, greater corrosion resistance ${ }^{10}$ (inferior to gold and platinum only), biocompatibility and good mechanical resistance. ${ }^{6,13}$ Some authors, however, have questioned the behavior of titanium brackets in fluoridated environment. ${ }^{3,14,22,24}$ The titanium alloys $\left(\mathrm{Ti}_{6} \mathrm{Al}_{4} \mathrm{~V}\right)$ and the cobalt-chromium alloys have also been used. Filmore, ${ }^{9}$ evaluating the soft temper cobalt-chromium alloy and comparing it to two titanium alloys, observed that the chemical composition and the thermodynamic treatment of the cobalt-chromium alloy present impact on its resistance to corrosion. Considering the peculiarities inherent to the oral cavity and the mechanical requirements during the orthodontic treatment, it is essential the development of more researches related to biocompatibility, mechanical resistance and anticorrosion properties of these alternative alloys, so they can settle as a possibility on the bracket manufacturing process. This study evaluates the corrosion of metallic alloys in artificial saliva with and without fluorides, evaluating the superficial aspects in scanning electron microscopy and the residual components, so that they can be used alternatively to stainless steel in patients hypersensitive to nickel.

\section{MATERIAL AND METHODS}

The sample consisted of 64 straight-wire premolars brackets, distributed in groups according to manufacturer and type of alloy (Table 1). Twelve groups were immersed in artificial saliva, pH 6,5 (Table 2), for periods of 7, 9 and 11 weeks and four in artificial saliva (pH 6,5) with $2 \mathrm{~g} / \mathrm{l}$ of $\mathrm{NaF}$ for 11 weeks. One sample was not immersed (Table 3 ).

The brackets were set with the aid of tweezers (Univer, Duflex, Rio de Janeiro, Brazil) in sterile Petri dishes, $90 \times 15 \mathrm{~mm}$, containing $50 \mathrm{ml}$ of artificial saliva, sealed and kept in kiln (EES, Olidef, Ribeirão Preto, Brazil) at $37^{\circ} \mathrm{C}$ constant, in static conditions.

Table 1 - Distribution of sample according to experimental groups.

\begin{tabular}{|c|c|c|c|c|c|c|c|c|}
\hline Brand & Lot & Alloy & Control group & Group 1 & Group 2 & Group 3 & Group 4 & Total \\
\hline Morelli Nickel- Free - Sorocaba, Brasil & 791448 & Ni-free steel & 1 & 4 & 4 & 4 & 4 & 17 \\
\hline Morelli Golden Line - Sorocaba, Brasil & 632079 & TiN coating & 1 & 4 & 4 & 4 & 4 & 17 \\
\hline TP Orthodontics - La Porte, USA & 1395LJR & $\mathrm{Co}-\mathrm{Cr}$ & 1 & 4 & 4 & 4 & 4 & 17 \\
\hline Dentaurum- Inspringen, Germany & 345360 & $\mathrm{Ti}$ & 1 & 4 & 4 & 4 & 4 & 17 \\
\hline Total & & & 4 & 16 & 16 & 16 & 16 & 68 \\
\hline
\end{tabular}

Table 2 - Artificial saliva composition (mg/l).

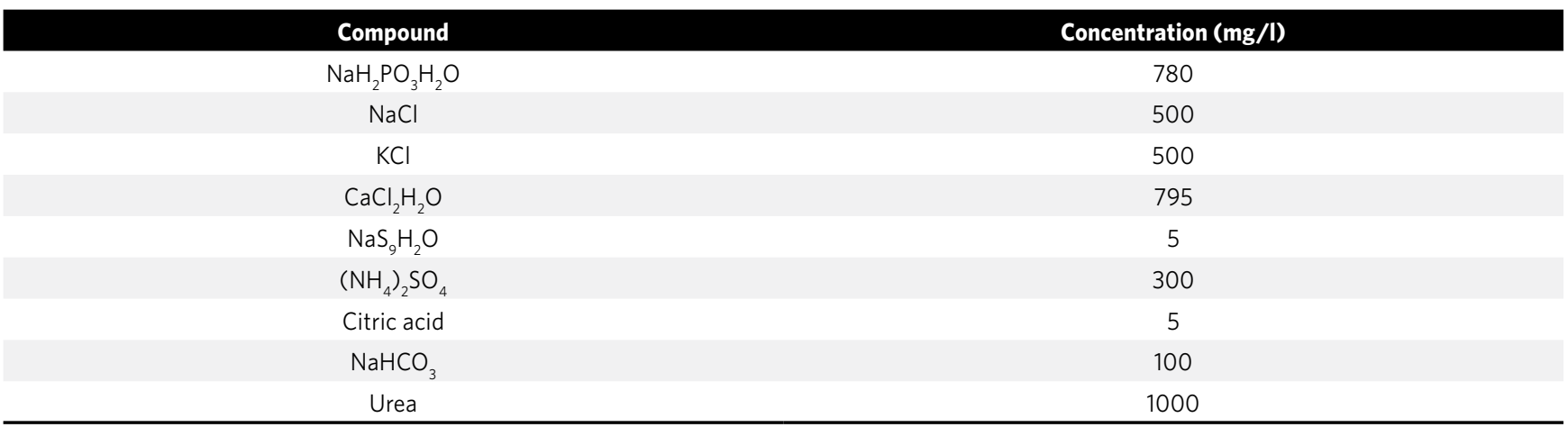


At the end of each week, about $3 \mathrm{ml}$ of saliva was replaced, preventing the solutions saturation by the corrosion byproducts. The corrosion process was qualitatively analyzed on the brackets surface through scanning electron microscopy (SEM) (JSM-5310, JEOL, Japan). The panoramic images were obtained with angulation of $60^{\circ}$ and magnification of $15 \mathrm{x}$. The tiewing area and region of transition between body and base of the bracket were selected to be evaluated with magnification of 200 and 500x. The chemical composition of surface residue resultant from the corrosive process was semi-quantitatively evaluated through SEM linked to EDS system (XL30, Philips, Eindhoven, Netherlands). Table 4 presents the alloys composition before the corrosive process.

The quantitative evaluation of released products concentration in solutions of artificial saliva by corrosion was performed by atomic absorption spectrophotometry (Varian 220 FS, New York, USA).

\section{RESULTS}

\section{Results for steel samples with low nickel concentration}

The visual inspection of brackets from the control group revealed a unibody architecture, having little porosity on the surface. The tie-wing area, underneath it and on the area of transition between body and base presented a quite irregular and rough surface, probably due to the difficult access to polishing in that region. On experimental groups immersed in artificial saliva it was observed color changes in isolated areas of the brackets that were proved time-dependent. It was not noticed superficial deposits suggesting corrosion. In the group of 11 weeks of immersion in solution of saliva with fluoride showed staining, granulation in all surfaces and some superficial deposit (Fig 1). The EDS analysis did not show formation of superficial oxides in measurable amount. The atomic absorption spectrophotometry did not identify ions release after 11 weeks.

\section{Results for steel samples with titanium nitride coating}

The visual inspection revealed that these brackets also present a unibody architecture. According to manufacturer, the bracket has the same chemical composition as the steel with low concentration of nickel, but a thin coating of titanium nitride (TiN) is applied. The control group presented a rough and irregular surface. On experimental groups immersed in artificial saliva, small whitish deposits were seen on all brackets that are more susceptible to surface defects for the TiN coating. Extending the immersion period, isolated granules were seen on the bracket surface and some cracks also could be noticed. A more intense corrosive process was noticed on these brackets when compared to the group with low concentration of nickel. On the group of 11 weeks in artificial saliva with fluoride it was observed greater granulation and formation of vesicles (Fig 2). In the semi-quantitative

Table 3 - Distribution of brackets groups according to period of immersion and solution utilized.

\begin{tabular}{|c|c|c|c|}
\hline Group of brackets & & Group of brackets & Corrosive solution \\
\hline Control group & Group 0 & O week & None \\
\hline \multirow{4}{*}{ Experimental groups } & Group 1 & 7 weeks & Artificial saliva \\
\hline & Group 2 & 9 weeks & Artificial saliva \\
\hline & Group 3 & 11 weeks & Artificial saliva \\
\hline & Group 4 & 11 weeks & Artificial saliva with fluoride \\
\hline
\end{tabular}

Table 4 - Initial chemical composition of the brackets alloys.

Chemical composition(\% by weight)

\begin{tabular}{ccccccccccccccccccc} 
Brand & $\mathrm{Fe}$ & $\mathrm{Cr}$ & $\mathrm{Ni}$ & $\mathrm{Si}$ & $\mathrm{Mo}$ & $\mathrm{Mn}$ & $\mathrm{Ti}$ & $\mathrm{W}$ & $\mathrm{Co}$ & $\mathrm{Cu}$ & $\mathrm{H}$ & $\mathrm{O}$ & $\mathrm{N}$ & $\mathrm{C}$ & stainless & TiN \\
Morelli Nikel-free & 64.69 & 17.5 & 0.01 & 1.0 & 3.5 & 12.0 & - & - & - & - & - & - & 0.8 & 0.2 & - & - \\
Morelli Golden-line & 64.69 & 17.5 & 0.01 & 1.0 & 3.5 & 12.0 & - & - & - & - & - & - & 0.8 & 0.2 & - & Superficial coating \\
Dentaurum & - & - & - & - & - & - & 99.0 & - & - & - & 0.06 & 0.35 & 0.35 & 0.05 & 0.3 & - & - \\
TP Orthodontics & 0.75 & 26.0 & 0.1 & - & 6.0 & - & - & 0.1 & 63.0 & 1.0 & - & - & - & - & - & - \\
\hline
\end{tabular}


evaluation of chemical composition of surface residues (SEM-EDS), it was identified the presence of titanium $(95,88 \%)$ and oxygen $(4,12 \%)$ which shows formation of oxides on the surface of the material, resultant from the corrosion (Fig 3). Despite the presence of this corrosion after 11 weeks, there was no significant amount of ions on the atomic absorption spectrophotometry, showing that despite the corrosion, the ions release in saliva was low.

\section{Results for titanium samples}

The titanium bracket from the control group presented the most irregular surface, full of fenestrations and increased rugosity in relation to the other brackets, despite also being unibody. This bracket presented little alteration and superficial deposits during the experimental period. Brackets from groups of 9 and 11 weeks of immersion in artificial saliva presented areas of staining and it was noticed the appearance of isolated granulation.
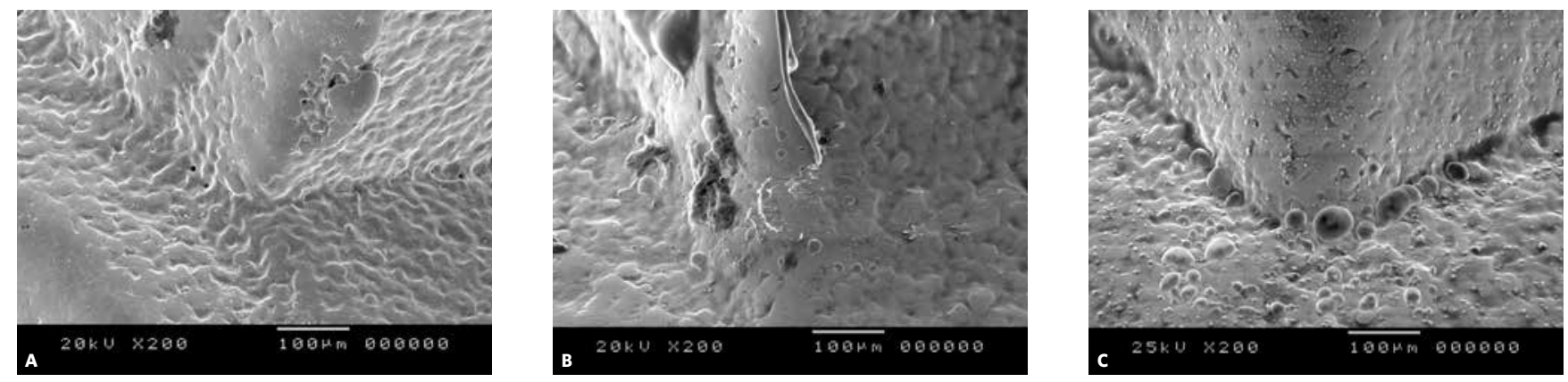

Figure 1 - Superficial aspects of the transition area between body and base of steel alloy with low nickel concentration brackets (magnification of 200x). A) control; B) 11 weeks without fluoride; C) 11 weeks with fluoride.
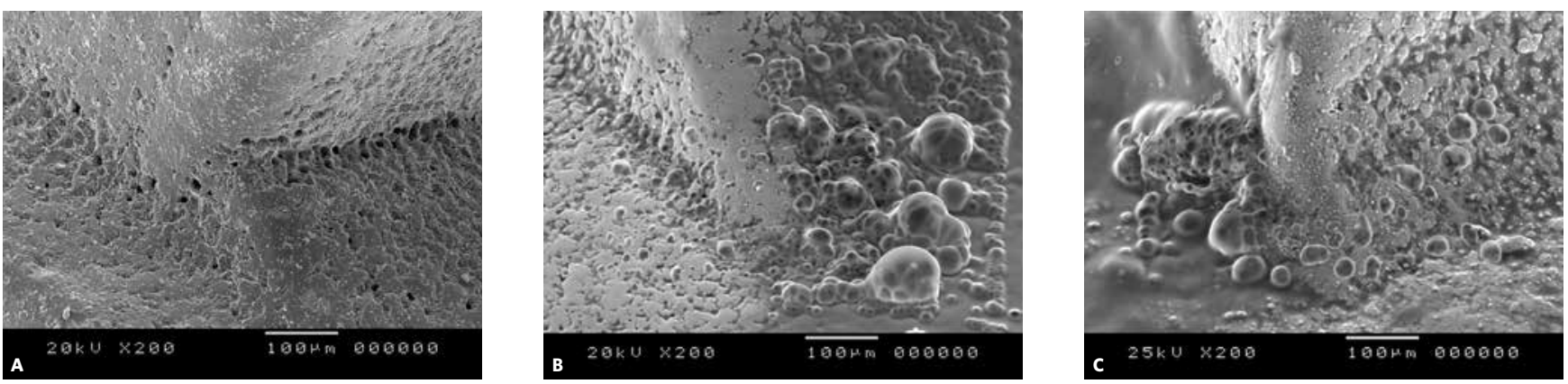

Figure 2 - Superficial aspects of the transition area between body and base of steel alloy with titanium nitride coating brackets (magnification of 200x). A) control; B) 11 weeks without fluoride; C) 11 weeks with fluoride.

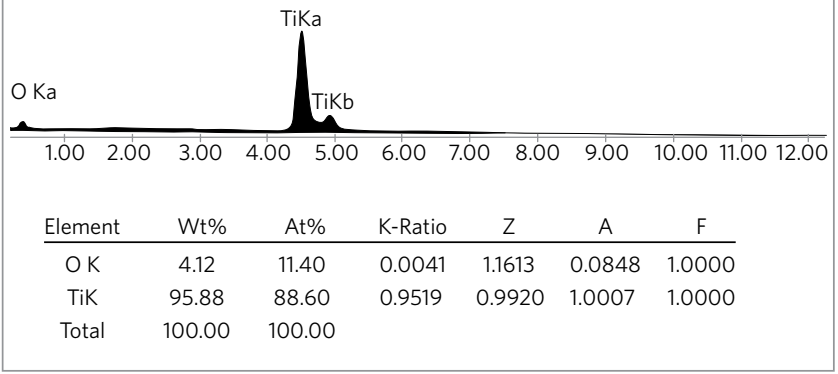

Figure 3 - Result of the SEM-EDS evaluation of chemical composition of surface residues from the titanium nitride alloy after 9 weeks of immersion. 
In the presence of fluoride, it was noticed an increase of these color variations and of granulations, which suggests a lower resistance of the titanium alloy to the fluoride (Fig 4). The EDS analysis did not show clear signs of oxidation and after 11 weeks, the solutions of saliva did not present measurable amount of ions on the atomic absorption spectrophotometry.

\section{Results for cobalt-chromium samples}

The assessment of the cobalt-chromium bracket proved to be the only one in the sample formed by two parts connected by a weld interface. The control group already presented staining on the surface and some porosity. The weld bead was irregular and with spongy aspect, which may facilitate the beginning of the corrosion process. Galvanic, intergranular and crevice corrosions are more frequent in brackets with soldering area. The experimental group showed the greatest alterations during experiment, when compared to the other tested alloys.
After 9 weeks of immersion in artificial saliva it was observed a great deposition of material in the soldering area. The sample of 11 weeks showed significant alterations, with formation of crystals on the body/ base interface, suggesting a deposition of corrosion byproducts in these areas. The group of 11 weeks in solution of saliva with fluoride experienced greater corrosion in relation to the others. The bracket presented a superficial granulated aspect, with formation of crystals and with release of metal chips from the surface of the bracket (Fig 5). The semi-quantitative analysis (SEM-EDS) of chemical composition of surface residues after 11 weeks of immersion in artificial saliva present a predominance of cobalt (50,86\%), chromium (19,32\%) and silver (16,83\%). The presence of oxygen $(5,98 \%)$ shows formation of oxides on the surface of the material (Fig 6). The analysis of the solutions by atomic absorption spectrophotometry did not show clear signs of ions release on the solution of artificial saliva.
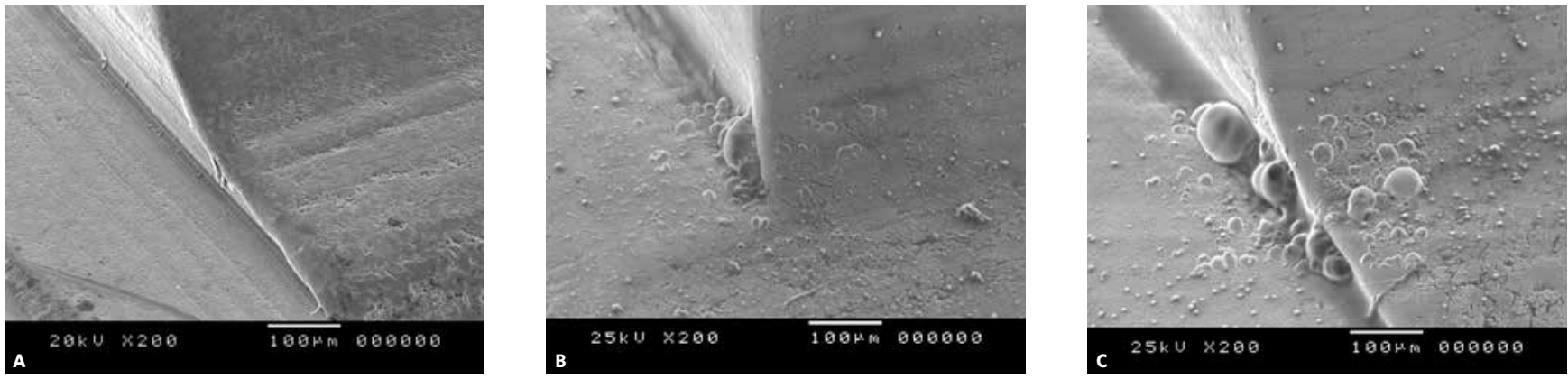

Figure 4 - Superficial aspects of the transition area between body and base of titanium alloy brackets (magnification of 200x). A) control; B) 11 weeks without fluoride; C) 11 weeks with fluoride.
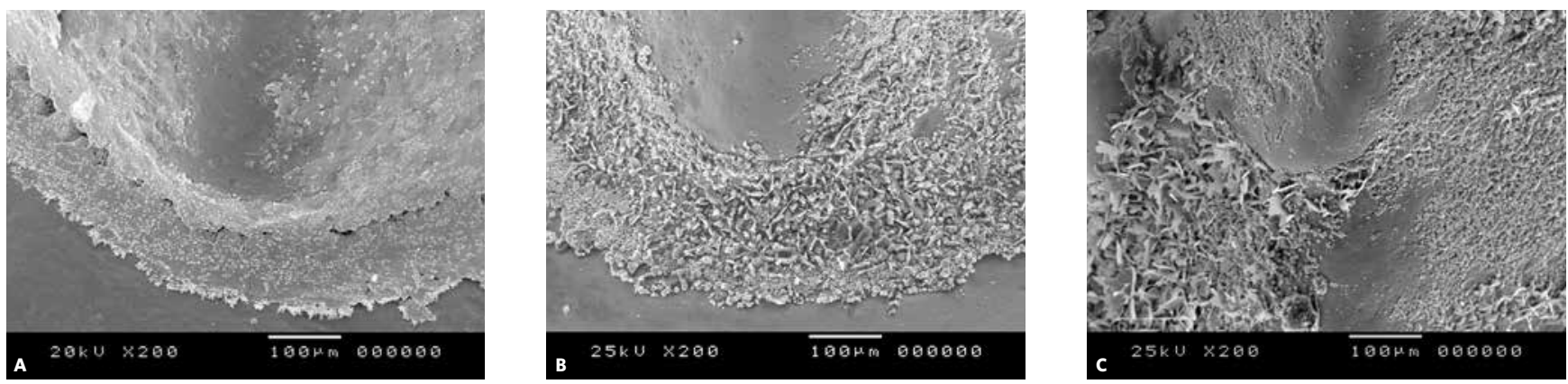

Figure 5 - Superficial aspects of the transition area between body and base of cobalt-chromium alloy brackets (magnification of 200x). A) control; B) 11 weeks without fluoride; C) 11 weeks with fluoride. 


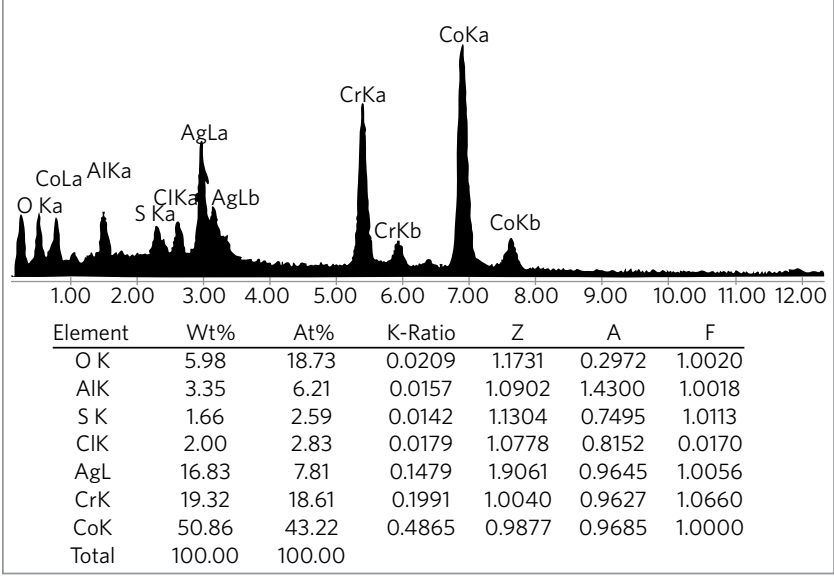

Figure 6 - Result of the SEM-EDS evaluation of chemical composition of surface residues from the cobalt-chromium alloy after 11 weeks of immersion.

\section{DISCUSSION}

The corrosion of metallic alloys used on the orthodontic bracket manufacturing process has been researched. The corrosion release of nickel and chromium ions has received special attention due to its potential carcinogenic, mutagenic and allergenic effects. It is estimated that about $10 \%$ of the population present allergic reactions to nickel. ${ }^{6,18,26}$ In the oral cavity this reaction can manifest through edema and gingival bleeding, often of difficult differential diagnosis in relation to periodontal inflammatory reactions of patients in orthodontic treatment and that present bad sanitation. The orthodontic industry have sought alternatives to minimize these allergic reactions, altering the composition of stainless steel alloy, reducing the concentration of nickel or using alternative alloys as titanium-aluminium-vanadium alloy, pure titanium, cobalt-chromium or superficial coating of titanium nitride. The present study evaluated the corrosion of some of these alloys, keeping the brackets immersed in solution of artificial saliva, $\mathrm{pH}$ 6,5, at constant temperature of $37^{\circ} \mathrm{C}$. Similar methodology was used by some researchers. ${ }^{1,6,10,16,20}$ Other works ${ }^{10,19}$ evaluated the bracket corrosion using solution of sodium chloride at $0,9 \%$. Although the solution of $\mathrm{NaCl}$ is potentially more corrosive than artificial saliva, no laboratory corrosive environment is capable to simulate every event that occurs in the oral cavity. The interaction between the characteristics of the human saliva, alterations of $\mathrm{pH}$ due to food variety, bacterial colonization and its byproducts make the oral cavity an extremely favorable environment to corrosive process and of difficult reproduction in vitro. ${ }^{5,6}$ The addition of fluoride to artificial saliva diminished the corrosion resistance in all tested alloys. Similar result was found in several works, ${ }^{3,10,14,15,17,23,25}$ indicating a greater susceptibility to corrosion in the presence of fluorides. Clinically, this fact represents a concern regarding cavity prevention in orthodontic patients, once that astringent solutions and fluoridated toothpaste, normally recommended as a way to prevent cavity, may increase the appliance corrosion, releasing greater amount of ions in the oral cavity. The evaluations of the microscopy images showed a different behavior of the alloys. The steel alloy with low concentration of nickel presented better performance when compared to the others. After 11 weeks submitted to the corrosive process it was not observed the presence of surface residues in the groups with and without fluoride. It was not identified the presence of oxygen on the EDS evaluation and the atomic absorption spectrophotometry did not reveal ions release. Similar results were found in a previous study ${ }^{19}$ although the saline solution was used as corrosive environment. The titanium nitride bracket presented greater galvanic and crevice corrosion process than the steel brackets with low concentration of nickel. Defects on this coating during the manufacturing process may facilitate it., ${ }^{2,620,21}$ Titanium brackets presented good resistance to corrosion. The titanium is considered a stable metal, biocompatible and resistant to corrosion. ${ }^{3,4,7,8,10,14,15,17,23,25}$ The analysis of the images showed little alteration, mostly, only chromatic, and even in presence of fluoride, the increase of alterations was not sufficient to cause ions release in the solution. The cobalt-chromium alloy was the one that presented lowest resistance to corrosion. The presence of fluoride increased the corrosion, indicating a low resistance to fluorides. Associated to this fact, these brackets were the only ones that presented a soldering area between the body and the bracket bases. The presence of this area and thermal treatment increase the susceptibility of this alloy to corrosion. . $^{7,8,9,16,20,21}$ The solutions saturated by corrosion byproducts were analyzed in order to verify the types and concentrations of released metals after the corrosion tests of the different samples in all three experimental intervals. The atomic absorption spectrophotometer 
is capable to quantify chemical elements in surfaces, solid materials and or solutions, through detecting its atoms. ${ }^{12}$ Several works about corrosion of braces $^{12,13,19,20,25}$ used the atomic absorption spectrophotometer to quantify chemical elements in these solutions. In the present study, this method proved that the corrosion of alloys, observed on the SEM, was of low intensity, with low ions release in the solution of saliva. This result suggests that the alloys used on the bracket manufacturing process presented fine biocompatibility and may be used on patients with nickel hypersensitivity.

\section{CONCLUSION}

Through interpretation of the results obtained from this study, we concluded that the cobalt-chromium alloy showed the greatest corrosion, quantitatively. The pure titanium alloys and the steel alloy with low concentration of nickel presented the greatest corrosion resistance. The presence of fluoride caused greater alterations in all tested alloys. The quantitative evaluations, through atomic absorption spectrophotometry, did not identify measurable amount of ions in the solution of artificial saliva, suggesting fine biocompatibility of the alloys.

\section{REFERENCES}

1. Barrett RD, Bishara SE, Quinn JK. Biodegradation of orthodontic appliances. Part I. Biodegradation of nickel and chromium in vitro. Am J. Orthod Dentofacial Orthop. 1993;103(1):8-14

2. Callister WD. Ciência e engenharia de materiais. $5^{a}$ ed. Rio de Janeiro: LTC;2002.

3. Conz MB, Soares GA, Ponciano JAC. Efeito da aplicação de fluoretos sobre a superfície de uma liga de Ti-AI-V. Rev Bras Implant. 2002;8(1):10-3.

4. Deguchi T, Ito M, Obata A, Koh Y, Yamagishi T, Oshida Y. Trial production of titanium orthodontic brackets fabricated by metal injection molding (MIM) with sintering. J Dent Res. 1996;75(7):1491-6.

5. Eliades T, Eliades G, Brantley WA. Orthodontic brackets. In: Brantley WA, Eliades T. Orthodontic materials: scientific and clinical aspects. New York: T Thieme; 2001. p. 143-71.

6. Eliades T, Athanasiou AE. In vivo aging of orthodontic alloys: implications for corrosion potential, nickel release, and biocompatibility. Angle Orthod. 2002;72(3):222-37.

7. Es-Souni M, Fischer-Brandies H, Es-Souni M. On the in vitro biocompatibility of Elgiloy, a co-based alloy, compared to two titanium alloys. J Orofacial Orthop. 2003;64(1):16-26

8. Ferreira TL. Avaliação da resistência à corrosão de materiais metálicos utilizados em aparelhos ortodônticos fixos [tese]. Rio de Janeiro (RJ): Universidade Federal do Rio de Janeiro; 2005.

9. Filmore GM, Tomlinson JL. Heat treatment of cobalt-chromium alloy wire. Angle Orthod. 1976;46(2):187-95

10. Gioka C, Bourauel C, Zinelis S, Eliades T, Silikas N, Eliades G. Titanium orthodontic brackets: structure, composition, hardness and ionic release. Dent Mater. 2004:20(7):693-700

11. Gontijo LP, Mazzieiro ET, Landre J Jr. Composição química e resistência mecânica da base de bráquetes straight-wire. Rev Dental Press Ortod Ortop Facial. 2004;9(4):52-9.

12. Goldstein Jl, Newbury DE, Joy DC, Lyman CE, Echlin P, Lifshin E, et al. Scannig Electron Microscopy end X-ray microanalysis. 2nd ed. New York: Plenum Press; 1992.

13. Grimsdottir MR, Gjerdet NR, Hensten-Pettersen A. Composition and in vitro corrosion of orthodontic appliances. Am J Orthod Dentofacial Orthop. 1992 Jun;101(6):525-32.
14. Hamula DW, Hamula W, Sernetz F. Pure titanium orthodontic brackets. J Clin Orthod. $1996 ; 30(3): 140-4$

15. Harzer W, Schröter A, Gedrange T, Muschter F. Sensivity of titanium brackets to the corrosive influence of fluoride-containing toothpaste and tea. Angle Orthod. 2001;71(4):318-23.

16. Huang $\mathrm{TH}$, Yen CC, Kao CT. Comparison of ion release from new and recycled orthodontic brackets. Am J Orthod Dentofacial Orthop. 2001;120(1):68-75.

17. Huang $\mathrm{HH}$, Chiu YH, Lee $\mathrm{TH}$, Wu SH, Yang HW, Su KH, et al. Ion release from $\mathrm{NITI}$ orthodontic wires in artificial saliva with various acidities. Biomaterials. 2003;24(20):3585-92

18. Kusy RP. Clinical response to allergies in patients. Am J Orthod Dentofacial Orthop. 2004;125(5):544-7.

19. Leite THM. Estudo comparativo do comportamento in vitro de diferentes bráquetes ortodônticos [dissertação]. Belo Horizonte (MG): Pontifícia Universidade Católica de Minas Gerais; 2003.

20. Maijer R, Smith DC. Corrosion of orthodontic bracket bases. Am J Orthod. 1982;81(1):43-8.

21. Matasa CG. Flaws in bracket manufacturing. J Clin Orthod. 1990;24(3):149-52.

22. Mondelli J. Ligas alternativas para restaurações fundidas. 1aㅡ ed. São Paulo: Panamericana; 1995.

23. Pröbster L, Lin $\mathrm{W}$, Hutteman $\mathrm{H}$. Effect of fluoride prophylactic agents on titanium surface. Int J Oral Maxillofacial Implants. 1992;7(3):390-4.

24. Profit WR. Aparelhos fixos contemporâneos. In: Proffit WR. Ortodontia contemporânea. $2^{\circledR}$ ed. Rio de Janeiro: Guanabara Koogan; 1995. p. 312-40.

25. Schiff $\mathrm{N}$, et al. Corrosion of titanium and its alloys in fluoridated and acidic environment. J Dental Res. 2002;81 Spec. Issue B, p. 273.

26. Staffolani N, Damiani F, Lilli C, Guerra M, Staffolani NJ, Belcastro S, et al. Ion release from orthodontic appliances. J Dent. 1999;27(6):449-54.

27. Von Fraunhofer JA. Corrosion of orthodontic devices. Semin Orthod. 1997;3(3):198 205 